City University of New York (CUNY) CUNY Academic Works

2015

The embodied crises of neoliberal globalization: The lives and narratives of Filipina migrant domestic workers

Wen Liu

City University of New York, The Graduate Center

How does access to this work benefit you? Let us know!

More information about this work at: https://academicworks.cuny.edu/gc_studentpubs/4

Discover additional works at: https://academicworks.cuny.edu

This work is made publicly available by the City University of New York (CUNY).

Contact: AcademicWorks@cuny.edu 


\title{
The embodied crises of neoliberal globalization: The lives and narratives of Filipina migrant domestic workers
}

\author{
Wen Liu \\ Critical Psychology, The Graduate Center, City University of New York, 365 Fifth Avenue, New York, NY 10016, USA
}

\section{A R T I C L E I N F O}

Available online $\mathrm{xxxx}$

\begin{abstract}
S Y N O P S I S
This paper theorizes the lives and working conditions of Filipina migrant domestic workers in Taiwan. To do so, I focus on the life stories of two migrant women-their struggles with exploitation and care, and their contradictory relationships with home and nation in transnational labor migration. These narratives detail crises of bodily sickness, racialized surveillance, and gendered violence across individual, social, and transnational scales, demonstrating the architecture of neoliberal globalization as a whole. These "embodied crises"-at once personal troubles and structural disasters-show how an overburdened care enforced through the labor of women of color violently affects their very own bodies, with ever-lasting consequences. Thus, using feminist analytic approaches of "critical bifocality" and "countertopography", I argue that these narratives are not individual tragedies, but rather circulate across places, bodies, and time, crafting a structural critique of neoliberal globalization that demands fundamental social transformation.
\end{abstract}

(c) 2015 Elsevier Ltd. All rights reserved.
Over 213 million migrants have been estimated to cross national borders annually, with a significant flow from the Global South to Northern capitalist advanced regions (United Nations Population Division, 2012). Within this cross-border movement, it has been estimated that there are around 53 million domestic workers worldwide, of which $83 \%$ are women since 2012. The stratified relations of care absorbed by the bodies of economically marginalized women are a result of the neoliberal dispossession of people's public goods and means of subsistence by state policies and multinational corporations. David Harvey (2003) has termed the process in which public assets and services are converted into privately owned goods "accumulation by dispossession". Social reproduction, as in the human need for welfare and the practices of caring, becomes a site of profits as neoliberal capitalism extends its territory by privatizing the sphere of care as private personal responsibility. Particularly, migrant domestic workers fulfill the social reproductive needs of families in capitalist advanced countries when the nation-state withdraws from public care.

Feminist scholars such as Glenn (2000), Parreñas (2000), Hochschild (2000), and Katz (2001b) have intervened in this discourse of "crisis in care" that only emphasizes the need for care of working families in Global North and neglects the crisis in care of migrant care workers themselves. While the migration literature has predominantly theorized this transnational movement through the unit of an aggregated migrant body, adopting a critical psychological lens of "bifocality", introduced by Lois Weis and Michelle Fine (2012), can contribute to the literature through situating the lived experiences of migrant women in the political-economic landscape of dispossession in care, highlighting the crises migrant women face and feel intimately as being inflected by structural crises of care. Within this approach, not only are the obstacles they encounter individualized tragedies, but they also represent the problematic architecture of global capitalism as a whole.

This paper is an attempt to theorize and empirically document the complexity of individuals moving across space and time in the context of neoliberal globalization, where women from the Global South are recruited to perform the reproductive labor of the Global North as low-wage workers. In this transnational movement, the collateral damage is deeply 
classed, gendered, and racialized, enabled by the sharp power asymmetries between nations and driven by capital's interest to accumulate more and more on an ever-widening scale, with increasingly severe social and individual consequences. Following the traditions of Kurt Lewin (1943), who has called for a topographical analysis of lives across space and time, the project places the narratives of these migrant women workers in the holistic landscape of capitalist globalization to excavate the roots of their obstacles and dilemmas as well as the embodied evidence of this global crisis. This approach echoes Marie Jahoda's (1982) interrogation of how the working-class body carries structural oppression and history, simultaneously being influenced by a situational force and becoming a force that acts upon it. Finally, the study attempts to recenter the narratives of working-class women who are migrants providing care in Taiwan while compromising their own and their families' needs in the Philippines.

For the migrant women workers who transgress national boundaries and the divisions of public and private through transnational care work, the scales of the global and the intimate constantly intersect and blur (Pratt \& Rosner, 2006). The impacts of neoliberal dispossession thus function on multiple scales in the circuits of the labor migration landscape. While the sites of nation-state and home traditionally provided subsistence and a safety net for their constituents who were exploited and alienated under class inequalities, now migrant workers become dispossessed by these institutions, providing care at the cost of their own needs as well as their participation in the public as full citizens (Parreñas, 2001a).

On the other hand, constructed under the capitalist mode of production as the "private" sphere, the site of "home" is often articulated as a place of belonging and of psychological stability and security. However, for migrant women who have left home to work abroad, the material burden of reproductive labor located in the patriarchal household in the home country is not discontinued-instead, it is intensified through their transnational care work (Parreñas, 2008). As a form of deeply affective labor (Boris \& Parreñas, 2010; Ehrenreich \& Hochschild, 2004; Pratt, 2012), domestic work often requires workers to act and care for their clients as "part of the family". Nicole Constable (1997) and Pei-Chia Lan (2006) noted that in the Chinese cultural context, the family analogy indicates not only respect but also responsibility for duties associated with traditional Chinese household. This analogy therefore becomes a coercive tool to frame all duties-physical tasks and the construction of emotional relationships-as "nonwork" and thus unlimited. In the two narratives of Filipina migrant domestic workers I will discuss in the paper, Elsa exchanged her own physical health and Jocelyn suffered from severe sleep deprivation to care for their clients' wellbeing. Their seeming inclusion in the domestic workplace therefore serves to disguise or justify migrant domestic workers' exploitative working conditions. In the landscape of globalization, home is not a place of belonging but rather of comfort and exploitative labor-a dialectic that is concealed at this intimate scale.

\section{Methodology and context}

This study of migrant women workers' lives is part of an ethnographic research project on Southeast Asian labor migration located at the migrant labor NGO, Taiwan
International Workers Association (TIWA). ${ }^{1}$ TIWA aims to advance migrant laborers' rights through legal advocacy and workplace organizing but also provide legal services and a grant-funded shelter for migrant workers. ${ }^{2}$ I used a multimethod qualitative research approach, which incorporated ethnography, participant observation, semi-structured individual interviews, and archival research, allowing me to document a wide range of data regarding the structural conditions of labor migration, public discourses about migrant workers, and the vibrant and intimate lives of the workers. I conducted a total of seven in-depth life story interviews with migrant workers, including five Filipina and two Filipino migrant workers. ${ }^{3}$

To invoke narratives beyond the immediate circumstances in which the workers were located, I asked them questions regarding their motivation to find jobs abroad, family background, working conditions in both the Philippines and Taiwan, communication methods with family, networks in Taiwan, and future plans. Through examining life deeply in multiple contexts, these narratives traversed the themes of structural constraints of globalized poverty, national policies, paradoxical feelings about families in the home country and employers in the workplace, and a sense of belonging in the NGO shelter alongside an urgency to move on. As I bore witness to their struggles and dreams, I was politically and ethically compelled to highlight my informants' lives within their repeatedly articulated moving circuits of constraints and possibilities, care and exploitation, which occurred at multiple scales.

This paper focuses on two in-depth life stories of Filipina domestic workers, to address the themes surrounding the dilemmas of the nation-state and home that emerged in all seven interviews. These two particular stories are emphasized because they represent the most extreme consequences of neoliberal dispossession among the migrant workers I interviewed, and they cover the widest extent of the scale that spans from the body to the nation-state. Their narratives illustrate the moments of rupture in which the combination of crises accumulated in the circuit of dispossessed needs was no longer resolvable through individual means, where the individuals' survival instead demanded structural transformation.

The migrant narratives are certainly gendered, not only regarding the nature of work but the concept of family. Among the female migrant workers I interviewed, all of them addressed their continual reproductive labor that extended from their domestic workplace to their families back in the Philippines, not only as a financial burden but indeed by psychologically sustaining their own survival under the adverse and isolating conditions in Taiwan. The two male workers I talked to ascribe labor migration to their extending of their personal life exploration and achievements. While they also support their families in the Philippines with their salaries, their narratives show little conflict between personal wellbeing and care for family members. The narrative of exploitation is inarguably a gendered one, but so is the strength that grows from a sense of interconnectedness between self and family, as the women's narratives do-circulating across places, bodies, and time, crafting a kind of transnational structural critique through their affective and physical embodiment of reproductive labor.

Due to the factor that the interviews were conducted at the NGO's shelter, the narratives portrayed some of the most drastic examples of labor exploitation, but also the ones from 
those who actively built solidarity with the organization in order to change their adverse conditions. In this sense, their experiences of exploitation fit into not merely a victim discourse of labor migration but a transnational structural critique. With their nation-state becoming a neoliberal coconspirator, workplaces reproducing the hierarchies at home, and communities coping with attacks from all angles, the narratives of migrant women transgress the boundaries of these spaces and binary of care and exploitation. The "critical bifocality" (Weis \& Fine, 2012) methodological approach emphasizes situating marginalized lives in the framework of structural constraints and possibilities, to not only reveal how individuals cope with their oppression but also highlight the fundamental inequalities that shape these lives.

The two narratives I selected demonstrate a kind of countertopography, termed by critical geographer Cindi Katz (2001a) to describe the analytical relations between distinctive places, which constantly jumped scale from individual crises to structural issues and exceeded the national borders of Taiwan and the Philippines. Robyn Magalit Rodriguez (2010) warns against examining the unequal and racialized policies enacted only by the host country in analyzing migrant domestic work, and encourages framing sending country as an active actor in the relationship-in this case, how the Philippines play an active role in facilitating out-migration to profit from the remittances of its citizens' labor. On the other hand, as documented in Francisco and Rodriguez's (2014) work, it is precisely because migrant women have been displaced by their home state as disposable laborers to a foreign land that antinationalist narratives grew from their experiences and became a source of structural resistance and transnational solidarity. Similar to the context of Francisco and Magalit's research, the migrant workers at the shelter have experienced abandonment from the Philippine state, and thus their narratives have been intertwined with structural critiques of their conditions instead of with self-blame or individualization. The lenses of critical bifocality and countertopography help to make sense how migrant workers are simultaneously mobile and immobile in the geography of transnational labor migration.

\section{The neoliberal markets of Taiwan and the Philippines}

Eager to insert itself into the global capitalist market, in the 1980s, Taiwan started to import cheaper labor while simultaneously investing productive capital in Southeast Asia. The Taiwanese state viewed importing low-wage migrant labor not only as a strategy to boost capital accumulation but also as a solution to the gap in reproductive care for the aging population as women's participation in the labor market increased (Lan, 2006). As a result, by mid-2013, around half a million migrant workers constituted at least $4 \%$ of the total labor force in Taiwan. Among all migrant workers, about $50 \%$ of them were engaged in paid care work, and of these a majority were female migrants from Indonesia, Vietnam, the Philippines, and Thailand (Bureau of Employment and Vocational Training, 2013).

On the other hand, neoliberal globalization has subjected Southeast Asian countries to severe foreign debt, widening the income gap and raising poverty rates, thus worsening the living conditions of everyday working people (Hsia, 2004). In an attempt to mitigate their national debt and surplus of labor under high rates of unemployment, the Philippines has facilitated the outflow of labor migration and exported their citizens as commodities. Female overseas contract workers are commonly depicted as "modern-day heroes" by the Philippines' national propaganda. Since the 1970 s, the number of workers exported abroad from the Philippines has escalated annually (Parreñas, 2001b). According to the National Statistics Office of the Philippines (2013), there were around 2.2 million Filipino migrant workers abroad in 2012 , more than $48 \%$ of them female and $31.3 \%$ unskilled laborers. This rapid increase of migrant labor from the Philippines is a result of the neoliberal demand for a class of increasingly flexible, cheap labor-women of color -in the service sector at the global scale.

The bodies of Filipina migrant workers are subjected to not only state regulation but also surveillance abroad, as the Taiwanese state implements strict racialized border control. Lan (2006) argues that such policies are designed to preserve relative ethnic homogeneity, in response to the threats to Taiwanese state legitimacy from the People's Republic of China. As a consequence, Southeast Asian migrants are relegated to perpetual "guest worker" status, deprived of citizen rights, and continually subjected to quota control and minimum wages. ${ }^{4}$ Between the outflow and inflow of labor migration, the nationless bodies of women migrant workers are forced to absorb the highest financial, physical, and emotional costs. In the following section, Elsa's narratives detail the high cost of caring labor at the expense of worker's own body.

\section{Results and discussion}

The crisis of nation-state: Elsa's breasts

"It helps me to know that I will leave in ten years. My life is for the next generation." - Elsa

I met Elsa at TIWA's shelter when she had just begun chemotherapy. She, a Filipina domestic worker in her mid-30s, found herself caught in an irresolvable dilemma when she was diagnosed with stage three breast cancer in the midst of her contract. Constrained by the duration of their contract, migrant workers' access to health care depends solely on their capability to labor instead of on universal "citizenship" in Taiwan. Therefore, a seemingly uncomplicated issue of workers' access to medical treatment became a problem of who would claim the body of the worker once it ceased to be "productive". Elsa's struggle highlights the intimate dilemma between care for one's body and the client's body that migrant domestic workers often confront, as their capacity for care is dispossessed for the profit-driven neoliberal care industry and no system is set up to sustain their well-being.

Elsa's relationship with her employers was relatively harmonious. She took care of their parents, whom she called "Grandpa" and "Grandma". However, the balance of the relationship started to tip when Grandpa was diagnosed with brain cancer. Elsa's workload suddenly intensified. Meanwhile, Elsa began to notice growing pain and itchiness in her left breast and swelling in her right breast, as well as an overall decreased energy level. Grandpa's illness was intimately tied with the fate of Elsa's breasts and prevented 
her from seeking immediate support for her own physical condition.

\section{Breasts and the nation}

A few months after Grandpa passed away, Elsa's doctor found cancer cells in Elsa's body and actively persuaded her to surgically remove her breast. However, she was caught in the moral and material dilemmas of whether or not to undergo surgery due to her own opposing physical needs. The health of her body was closely connected to her ability to take care of not only her other client, Grandma, but also her own daughter in the Philippines. She said,

I can't accept the fact that I need to take out my one breast, because my friend said, "If you take out your breasts, you will die." I feel nervous and I think about my daughter, because I am the only one who is taking care of her.

In the neoliberal regime of personal responsibility splitting "good" women from "bad" women, Michelle Fine (2010) argues how breasts become significant political-economic objects that "swell" on women's bodies as mothers, wives, and daughters and stretch their capacity to bear the neglected social-reproductive needs in a neoliberal state. In the Taiwanese context, Southeast Asian migrants are often hypersexualized to place moral barriers on sexual relationships between them and their Taiwanese clients in the domestic sphere, in order to establish as an ethnically purified "Chinese" nation (Lan, 2008). Breasts, the sexualized organs that mark migrant women as both sexual agents and potential mothers, are therefore the site of representational struggles of the morally indecent "bad woman" and the racialized "bad mother" in the Taiwanese context. In the narratives, Elsa's breasts became the embodiment of her struggle to remain simultaneously a good mother, an employee, and a woman with dignity despite the racialized and gendered exclusion policies in Taiwan that reject perceiving migrant women as whole people.

As Elsa's body was physically displaced from home and subject to racialized sexual control, her breasts also became the affective site of connection between her present existence and her life in the Philippines. She vividly recalled her friend in the Philippines persuading her not to proceed with the operation, saying, "Your life depends on your breasts." Elsa needed the "bad breast" of failed motherhood to be removed so that the "good breast" of her able body could continue to labor for her daughter. However, the risk of removing the breast with disease was intimately connected to her continued ability to work. Elsa's dilemma regarding her own physical condition thus became a metaphor for her paradoxical position as a sick, "unproductive" worker in Taiwan-the illness in her body had to be eradicated so that her labor-power could be restored. However, her legal residence and access to health care in Taiwan depended solely on her labor contract, that is, her capacity to work. Neither the Taiwanese nor the Philippine state provides resources or mandates that allow migrants to receive treatments while not working, as their bodies are seen as replaceable and "unworthy" of care.

Not only was the illness of Elsa's breast a threat to her daughter's and her own survival, but it metastasized to her employers and their mother, Grandma. Elsa continually expressed a genuine concern for Grandma's wellbeing. She said, "I didn't go through the operation right away, because if I do the operation, who would take care of Grandma? ... I said [ to the employers], 'No operation is okay. I will just wait for my time."' In this case, the emotional engagement in the domestic workplace becomes a means of domination, in which workers, attached to their clients, are entrapped by the hierarchical relationship of who is worthy to be cared for. Elsa's case shows the productive work of caring affect in the domestic workplace that enforces the worker's self-discipline. The discipline is not executed by the "bad boss" or explicit forms of domination but through neoliberal ideological forces, in which Elsa took sole responsibility for not only her "bad breast" but also the wellbeing of her family and her client.

Under the pressure of their elder's needs, Elsa's employers were forced to make a decision regarding whether to replace Elsa with another worker. Desperately, the employer offered her $150,000 \mathrm{NTD}^{5}$ for her medical fees if she went home to the Philippines, which Elsa knew would be insufficient for treatment and the financial needs of her family and she would literally "wait for her time" to die. The "nice boss", in the end, could only offer an economic solution to a relationship built upon primarily economic exchange instead of the longterm reproductive needs of the worker.

\section{The nationless and replaceable body}

In the midst of the crisis, both Elsa and her employers sought help from the government and the broker agency but the lack of protection of migrant workers' health, such as paid sick leaves in the legal contract overall, became a major weakness in their case for Elsa to remain in Taiwan while unable to work. Elsa first sought help from the Manila Economic and Cultural Office (MECO), ${ }^{6}$ but its representatives' response to Elsa's situation, as she described it, was cold and indifferent: "Okay, you can stay here, but you have to pay. Your boss will pay?" To MECO, it was not necessarily an issue of legality to maintain the well-being of the workers, but of financial resources, which they unwaveringly declined to provide. She then contacted the Foreign Workers Counseling Center (FWCC) of the Taipei City Government. ${ }^{7}$ She described their response: "The FWCC people said, 'Why do you come here for sheltering? You are not a runaway. Your employer treats you bad? Your employer spanks you until your face bleeds?'” Unlike MECO's response, the FWCC's refusal to support Elsa was framed as not a financial issue but a categorical denial. That is, she was not "victimized enough"-facing physical abuse by the employers-to be helped.

Furthermore, the response of Elsa's broker agency, which mediates between the Filipino and Taiwanese states to find placements for migrant workers, was ruthless and revealed its sole motivation to be profits. Elsa said, "My broker told my employer that there was nothing they could do about my situation. They would send me back to the Philippines and hire a new migrant worker for my employers." She particularly recalled how the wife of her broker agent, a Filipina, threatened her in Tagalog in front of her employers, to not undergo the operation because "she would just die in ten years anyways". Elsa said, "So that I'm replaceable [emphasis added]. They don't care about me." 
Needs displaced as excess

Elsa's narratives repeatedly referenced her client' and daughter's needs and not her own. Her needs were not only financial but also affective and moral, as Elsa articulated that her initial desire to work abroad was for the "dignity" of her family. She revealed that part of the reason that she left the Philippines initially was to break away from the stigma of being a single, unmarried mother. She said,

I pity my father, because all of us are daughters and got married early, especially I got a daughter without a father. So I need to work to bring back the dignity of my family [emphasis added]. That's why I gave birth to my daughter and I flew abroad to work here in Taiwan. I like here, so actually I don't want to leave this place. If there is any opportunity, I don't want to live in the Philippines, because the government and some neighbors would say, "Oh, you got a child without a father." If I didn't have this kind of sickness, I want to work in Canada [emphasis added].

As a working-class Filipina woman, Elsa's body is subjected to constant patriarchal policing across the spatial and temporal trajectory of her migration. Waged work became an attainable solution for her to regain personal and family dignity under the forces of neoliberal globalization. However, the burdens of being an unwed mother and a woman without "proper breasts" were seen as undignified and even "trashed her dreams", as she described. When I asked what her hopes and plans were, she spoke of a potential marriage plan she had called off because of her fear of her boyfriend in the Philippines finding out that she was "no longer complete" after her mastectomy. While she rejected the dichotomy of "good mother" and "bad woman" and continued to take pride in her ability to provide for her daughter as a single mother, she was not left with many options to be all-a mother, a daughter, and a lover-at once.

The neoliberal ideology of personal responsibility, state policies, and the affect of caring labor at the domestic workplace work together to construct an "unproductive" worker's needs as "excess", and the worker as unworthy of being cared for. The displacement of the sick woman worker's body, which is marked as a "disused factory" (Cresswell, 1997) outside of commodity-production relations, becomes justification for the lack of social support and the state's neglect of her human value. Here, migrant women's needs are constructed as excess-unnecessary, risky, and prone to diseases, but "there anyway" (McClelland \& Fine, 2008, p. 85). This excess of needs leaks out of the borders of nation-states and becomes embodied in Elsa's constant negotiation between her and others' needs and the conflictual meanings of "good" and "bad" breasts.

\section{Dreams continue}

In Elsa's case, her displaced needs can only be fulfilled through the construction of hope and the "geographical imagination" (Harvey, 1990) of somewhere outside of the immediate circumstances constrained by capitalism. The excess of needs becomes a permanent "stage of wanting" (McClelland \& Fine, 2008, p. 85), demanding a more affluent future for those she cares for. As she calmly articulated, "It helps me to know that I will leave in ten years. My life is for the next generation." The temporal limits of her body in a way comforted her, while the continuation of time via her daughter sustained her affective capacity to live. Under the conditions in which her struggles were no longer resolvable through the meritocratic ideology of "trying her best", for Elsa, it was through the aspiration to continue her labor migration in Canada that she could imagine materializing her need to be a mother, to be a daughter, and for personal dignity. The spatial separation between her immediate location and "Canada" as an ideal space in a way reserved her capacity to labor (for somewhere with assumed "better" working conditions). The hope for the "next place" keeps migrant women in the circuit of labor migration, moving them from the immediate circumstances to the "future" and the next destination. As Elsa's body is confined by the forces of capital and nation, her dreams continue to travel on the global path.

\section{The crisis of home: Jocelyn's escape}

"I make myself strong so that I can work. It's okay if I'm tired because it's better in Taiwan than in the Philippines. It helps me also to go far away from my husband. I have my freedom." Jocelyn

When I spoke to Jocelyn, a Filipina domestic worker in her early 30s, at the TIWA shelter, her narratives about home from her rural childhood in the Philippines shifted to a series of painful events; she told me, laughing softly, "I am a battered wife before in the Philippines." The internal crisis of her marriage lasted for an entire decade, eventually expanding outward and forcing her to find a more permanent solution for herself and her children. She vividly described the night when her husband attacked their son and she finally decided to escape home:

I was full of blood, my face ... I grabbed some knives so I could run ... I held my kids, then I ran. I could not feel that I ran but only in my mind I was running away [emphasis added] ... maybe 100 meters away then I fell down. When I woke up, I was already in the hospital. And the doctor asked my name, I didn't know already. For almost one hour I was thinking and thinking what is my name.

Jocelyn described the event as an almost out-of-body experience that she had already rehearsed repeatedly in her mind. The crisis of structural violence from the state-poverty and lack of social support-to the crisis of domestic violence at home was absorbed and endured in Jocelyn's body and eventually instigated her impulse to leave the "self" that was overburdened with violence. She indicated her relief when she dissociated from her body and forgot who she was in the midst of her escape.

\section{Racialized surveillance in domestic workplace}

Jocelyn eventually applied to work abroad. Nonetheless, she found herself in another abusive home when she started her job as a domestic worker in Taiwan. Though she had grown up in poverty, Jocelyn described herself in the Philippines as an "independent woman" who initiated business opportunitiesselling things from coconuts to pork-and paid for her own college tuition. However, her narratives about domestic work 
in Taiwan described a level of exploitation that is beyond class and was intensified by the employers' racialized surveillance of her as a Southeast Asian worker. The employers were an uppermiddle-class Taiwanese family whose house in Taipei was a "luxury house" where Jocelyn "could never finish work because the house [was] so big and so clean." In addition to the daily household chores, Jocelyn took care of the employers' eightmonth-old son throughout the night. She explained that because the employers were concerned for their son's safety under her watch, they installed a surveillance camera in his room. Jocelyn further explained that, in order to prohibit her from leaving the house, they installed another surveillance camera at the front of the house, and a security guard controlled her movements in and out of the house-she was unable to leave without her employer's permission.

The psychological stress of being under 24-hour scrutiny on top of the severe sleep deprivation from working almost $20 \mathrm{~h}$ a day eventually drove her body to extreme exhaustion so that she "could not feel half of the body anymore". While she had been accustomed to this amount of work in the Philippines, the exhaustion at the domestic workplace became complicated due to its involving caring for another person and having to negotiate racial tensions. The fear of failing her obligation to care for the employer's son was one of the main motivations for Jocelyn's eventual escape from the house. She said,

I always prayed that God help me go out of the house. Overworked in the day and slept with the baby at night ... When the baby doesn't sleep you have to rock the baby in arms, and sometimes I nearly fell asleep. I was really afraid that I would drop the baby and I would be the one to blame.

In the domestic workplace, the caring relationship between the worker and the client becomes a mechanism of worker surveillance on its own. The "ethics" of being responsible for another individual's well-being subjugates the worker's own need to the client's. The intimacy of care work in the private household does not make labor any easier but only intensifies the emotional exploitation and control of the workers.

\section{Running as a political act of the exploited body}

The constant physical and emotional exhaustion at work that had accumulated in Jocelyn's body eventually drove her to plan her escape. Similarly to Elsa, Jocelyn knew that her body was the means for her own and her children's survival and was not replaceable as goods for money. She said, "I can always find money as long as my body is good. What if I have money but my body is worn out? I have three kids to take care of." For Jocelyn, like Elsa, no monetary value could buy off her bodythe only living mechanism that could fulfill her needs in the long term.

Through Jocelyn's Filipina network, she was connected to TIWA, and the staff helped her plan the logistics of leaving her workplace. She set the day of her escape while she was driven to her employers' factory to do extra labor on one weekend, so that she could pass the security guard without being questioned. The first night I talked to her in the shelter, she vividly described the anxiety, fear, excitement, and power she felt when she ran away from the workplace:

I saved my medical records, and took a picture of the house on my phone so that I have evidence ... I ran away during the break time. My muscles ached and my legs were sore from work, but I remember I was just running and running and running [emphasis added] ... I don't even remember what bus I was taking to get to the Taipei Main Station. I can't look back. I left all my stuff in the employers' house. I had nothing with me, only the clothes I was wearing.

Jocelyn's description of her escape from the workplace strongly mirrors her depiction of her escape from her husband, in that she seemed to be in a frenzied emotional state infused with excitement and fear. It was during the moment of escape that the accumulated pain and exhaustion in her body finally cracked a hole on the enclosed walls of "home" and were released. Instead of dissociating from the "self", as she described in her first escape from home, during her escape from the workplace, she reconnected with the sensations of her body ("my muscles ached and my legs were sore") and broke from the abusive past ("I can't look back").

While running is often criminalized and loaded with the moralistic discourses of trafficking, in which women and girls are often portrayed as victims of sex trafficking fleeing from abusive situations and transgressing legal boundaries (Kempadoo, Sanghera, \& Pattanaik, 2005), Jocelyn's escape was an incident of not only exile, but also desire, freedom, and flight. In the process of planning the escape, she plotted ways to reveal the injustice in her workplace through gathering evidence in advance. I commented on how I thought her escape was a very courageous act. She said, "I was scared but I wanted to fight." She elaborated, "It's for the future [emphasis added]. I don't want other Filipina come here and become like me." The diasporic Filipina community, imagined or concrete, served as an important physical and emotional infrastructure that placed these individual tragedies into a web of collective struggles. In Jocelyn's case, her fight was about not only her personal crisis but the future of migrant Filipina workers.

Through Jocelyn's case, I came to understand that the crises of neoliberalism travel not only vertically, between structural and individual levels, but also across temporal and spatial scales. The patriarchal violence that drove Jocelyn to escape from her home in the Philippines was part of the same process of neoliberal dispossession that created the conditions of her exploitation in Taiwan. In other words, neoliberalism extracts resources and eliminates public support, making women more vulnerable to abuse, and at the same time, it intensifies the racialized surveillance and exploitation in the domestic workplace abroad. In this sense, the dilemma and ambivalence that migrant domestic workers feel about "home" parallel the exploitative patriarchal relations extended from one domestic space to another. Instead of transforming women's oppression as it plays out in their traditional economic dependence on men, waged care work expands the unpaid reproductive work in labor migration and reinscribes the patriarchal division of labor on a global scale.

\section{The possibility of dignity and freedom}

Nonetheless, for many migrant women, "home" is a place of not simply continual violence, distress, and burden, but also strength, happiness, and pride. Many feminist scholars such as Geraldine Pratt (2004) and Christine Chin (1998) have documented the sense of financial autonomy and political agency and solidarity forged with other migrant workers that 
migrant women experience away from their home country. Jocelyn said, "The happiest I ever felt was when I sent money to my family and they said thank you. I only received salaries twice from the house but still we were happy." In order to survive, migrant women such as Jocelyn, and also Elsa, are forced to comply with the commodification of their labor. At the same time, they reject seeing their bodies as possessing purely monetary-exchange value and refuse to trade their long-term well-being for monetary offers. In other words, while they see their bodies possessing the labor-power for monetary exchange, they reclaim ownership of their bodies when they think about their own needs-caring for family, life, happiness and safety, and dignity and freedom as individuals.

Jocelyn especially emphasized her desire for her story to be heard by other migrant workers, having participated in the broader migrant labor struggle with TIWA even though she never went to a single protest in the Philippines. She said, "I got lucky that I met the TIWA people so I could leave my previous employer, but what about all the other migrant workers? I want them to get help, too." These migrant women's narratives insist on complicating a purely materialist analysis of labor as exploitative or economic by accounting for dignity, autonomy, and solidarity. Beyond the debates about the wage or value of reproductive work, their life stories assert the necessity of a humanitarian vision of rights and a sustainable life.

Through my extensive interviews with several migrant workers while spending three months working at the shelter, I felt humble receiving the incredibly rich life stories they presented to me, which overthrew the dualistic portrayals of migrants in mainstream Taiwanese discourse as either victims of global capitalism or criminals who walk between legal boundaries. In reality, many of them took pride in their work, even under the most adverse conditions, while understanding their struggle for freedom as being confined by structural instead of personal limitations. Their narratives revealed their desire not only to be present, or heard, but also to be seen as a whole person, with contradictions, who owns their faults and inadequacies-that is, they resisted being defined by the moral binary of "good" versus "bad" worker, woman, or mother (Fine, 2010).

\section{Diasporic (mis)connections}

During my fieldwork, as a Taiwanese person with a higher education background in the US, I was worried that I would be immediately read as someone who reflected the oppressive identity of the employers or the Taiwanese bureaucrats. However, through their experiences dealing with the profitdriven Philippine state, they had witnessed how having the same ethnic or national identity does not automatically equate to loyalty or concern for their welfare. It is in fact the Taiwanese organizers at TIWA that fought for their rights alongside these workers. Therefore, my Taiwanese identity did not become a barrier to building trust with the workers at the shelter. Some workers even connected with me through our shared migration experiences-I am an immigrant of color in the US who, while obviously belonging to a very different class of global migration, is nonetheless uprooted in the host country. Our different structural positions became apparent at the end of the shift at the shelter-I was the person who could leave freely, and their mobility was constrained by their visa and employment status.

I went back to TIWA a year after my fieldwork in the hopes of connecting with the people I interviewed and getting feedback for my analysis, but they either could not settle their lawsuits and went back to their home country or found other employment in Taiwan and lost contact with the organization. In the past four years, TIWA also went through a drastic change in leadership that began a year after my fieldwork. My inability to reconnect with them is indubitably a methodological limitation of this research, but it also demonstrates the normalized transitory conditions of both migrant labor and grassroots NGOs overall in Taiwan, in which collective knowledge and political struggle are difficult to sustain under the conditions of workers' temporary visa status, instability of organizational resources, and other structural constraints. The last time I heard from the organizers, in the winter of 2014, Elsa had moved back to the Philippines and was able to continue her treatments back home, and Jocelyn had found a factory-based job and stayed in Taiwan. I believe that the feminist analytical strategy I could apply here is to document their struggle and despair, as I heard it in their narratives, but also their resistance and hope for an alternative future-the refusal to reduce their complex experiences of migration to explanations of structural inevitability or personal tragedy.

\section{Conclusion: embodied crisis as an analysis of lives in structure}

As feminist scholar Marie Jahoda (1982) pointed out decades ago, individuals adjust their bodies, minds, and expectations to their material circumstances, and at the same time attempt to reshape or break out of them. Through working with migrant workers, I came to realize how larger political economic crises do not merely act upon the individual, but are negotiated, absorbed, and-at the moments of rupture-break out of women's bodies. I frame this interaction, between the structural crisis and individual response, as "embodied crisis", to depict the constantly shifting effects of the social and the individual, as well as the contradictory relations between production and social reproduction, in the current historical moment. The embodied crisis is not a one-sided tragedy of marginalization or exploitation, but rather, it reflects how the structural consequences of neoliberal dispossession push women to negotiate the commodity values of their bodies and their relationships with those surrounding them in the globalized world. In short, embodied crisis demonstrates the moments of rupture in which individuals can no longer absorb the structural crises-of neglected needs, lack of care, state violence, and labor exploitation-and thus enact these crises through their very bodies to call for transformative, fundamental change.

\section{Crisis in bodies and bodies in crisis}

As neoliberalism spreads and the public sheds social reproductive responsibilities, the overburdened care that is enforced in and branded onto the bodies of migrant women by capital produces crises in their very bodies. While a small incident such as illness, delayed paycheck, or miscommunication at the workplace can mostly be resolved individually, the combination of crises are common under the lack of structural 
support for migrant women and can lead to long-term devastating consequences. As migrant women workers become the sole financial providers for their families back home and the bearers of the economic burden of the nation, the crisis also spreads from their individual bodies across the geopolitical scale, of the individual, social, and transnational, leading to collateral damages to those they are obligated to care for. To return the blame from the individual gendered body to the exploitative circuits of global labor migration, this paper has demonstrated how the crises migrant women face are produced and reinforced by the structural locations in which they are situated and embodied in their experiences of exclusion from citizenship, separation from their families, and violence at home and in the domestic workplace.

All too often, capitalist crises are framed as something incidental, which can be fixed by implementing rational austerity measures or creating the rational subjects of consumers and workers. Nonetheless, an analysis through the lens of individual lives shows how the manufactured crises of capital are circulated and accumulated on bodies, particularly the bodies of poor women of color. Therefore, for migrant women, to care for others is to reproduce more unattended needs for themselves, since they are forced to exchange their capacity to care for themselves with the capacity to care for others in the profit-driven, neoliberal regime. This inverse relationship of care and need results in the crises they embody as sickness and escape from home in two Filipina migrant domestic workers' lives. Both cases represent the dilemmas between care and exploitation, desire and economic rationality, and risk and liberty as the neoliberal market constructs these relations as simultaneously conflictual and coexisting (Ong, 2006). Therefore, the embodied crises reflect a subjectivity that is deeply affective and sensuous, which contradicts hyperrational neoliberal subjectivity and reveals the instability of global capitalist relations as a whole.

The notion of embodied crisis not only applies to migrant domestic workers but also echoes the consequences enacted by an ever-growing underskilled and feminized workforce globally. Under these shifting social relations-where safety nets are being dismantled, the social is largely denied, and collective responsibility is stuffed into individual bodies-cross-level analysis on women's lives and social structures has become even more crucial. This paper is thus part of an effort to rejoin the psychological attention to individual subjectivity with the multi-disciplinary analysis of structural processes as they live in, and are resisted through, bodies.

\section{Acknowledgments}

Thanks especially to my mentor, Michelle Fine, for providing me support throughout the research and writing process.

\section{Endnotes}

\footnotetext{
${ }^{1}$ As part of the fieldwork, I joined the TIWA community as a volunteer in the summer of 2011, assisting with case counseling on migrant labor disputes, translating organizational materials, and working the weekly nightshift at the workers shelter

${ }^{2}$ In 2011, TIWA consisted of a group of six paid, full-time staff, who were mostly Taiwanese, and two affiliated migrant worker groups, one Filipino and one Indonesian.

${ }^{3}$ The interviews were done in either English or Mandarin Chinese, whichever my informants preferred. Due to my language capacities and the
}

organizational demographics at the time, I mostly interacted with Filipino/a migrant who spoke English.

${ }^{4}$ As Lan (2006) notes, low-skilled migrant workers are only allowed to stay in Taiwan for a maximum of three-year contracts. While the work permits for upper-class migrants, mostly from Western countries and referred to as "whitecollar foreign professionals", are granted on an individual basis and include the right to apply for permanent residency and transfer among different employers, working-class migrants are deprived of these rights.

${ }^{5}$ Equivalent to around \$5000 USD.

${ }^{6}$ MECO is the official representative of the government of the Philippines in Taiwan, which oversees the regulation of Filipino migrant workers' visas and permits.

${ }^{7}$ FWCC is an organization supervised by the Council of Labor Affairs of the Taipei City Government that assists the affairs of foreign workers in Taiwan.

\section{References}

Boris, E., \& Parreñas, R.S. (2010). Introduction. In E. Boris, \& R.S. Parreñas (Eds.), Intimate labors: Cultures, technologies, and the politics of care. Stanford, CA: Stanford Social Sciences.

Bureau of Employment and Vocational Training (2013). Foreign workers in productive industries and social welfare by nationality and sex. Retrieved from: http://statdb.cla.gov.tw/html/mon/c12050.pdf

Chin, C.B. (1998). In service and servitude: Foreign female domestic workers and the Malaysian "modernity" project. Columbia University Press.

Constable, N. (1997). Maid to order in Hong Kong. New York: Cornell University Press.

Cresswell, T. (1997). Weeds, plaques, and bodily secretions: A geographical interpretation of metaphors of displacement. Annals of the Association of American Geographers, 87(2), 330-345.

Ehrenreich, B., \& Hochschild, A.R. (2004). Introduction. In B. Ehrenreich, \& A.R. Hoschschild (Eds.), Global women: Nannies, maids, and sex workers in the new economy (pp. 1-12). New York: Henry Holt and Company, LLC.

Fine, M. (2010). The breast and the state: An analysis of good and bad nipples by gender, race and class. Studies in Gender \& Sexuality, 11, 24-32.

Francisco, V., \& Rodriguez, R.M. (2014). Countertopographies of migrant women: Transnational families, space, and labor as solidarity. Working USA, 17(3), 357-372.

Glenn, E.N. (2000). Creating a caring society. Contemporary Sociology, 29(1), 84-94.

Harvey, D. (1990). Between space and time: Reflections on the geographical imagination. Annals of the Association of American Geographers, 80(3), 418-435.

Harvey, D. (2003). The new imperialism. New York: Oxford University Press.

Hochschild, A.R. (2000). The nanny chain. The American Prospect, 11(4), 32-36.

Hsia, H.C. (2004). Internationalization of capital and the trade in Asian women: The case of "foreign brides" in Taiwan. In D.D. Aguilar, \& A.E. Lacsamana (Eds.), Women and globalization (pp. 181-229). Amherst, NY: Humanity Books.

Jahoda, M. (1982). Employment and unemployment: A social-psychological analysis. Cambridge: University Press.

Katz, C. (2001a). On the grounds of globalization: A topography for feminist political engagement. Signs, 26(4), 1213-1234.

Katz, C. (2001b). Vagabond capitalism and the necessity of social reproduction. Antipode, 33(4), 709-728.

Kempadoo, K., Sanghera, J., \& Pattanaik, B. (Eds.). (2005). Trafficking and prostitution: Reconsidered new perspectives on migration, sex work, and human rights. Boulder, CO: Paradigm Publishers.

Lan, P.H. (2006). Global Cinderella: Migrant domestics and newly rich employers in Taiwan. Durham and London: Duke University Press.

Lan, P.C. (2008). Migrant women's bodies as boundary markers: Reproductive crisis and sexual control in the ethnic frontiers of Taiwan. Signs, 33(4), $833-861$

Lewin, K. (1943). Defining the "field at a given time". Psychological Review, 50(3), 292-310.

McClelland, S., \& Fine, M. (2008). Rescuing a theory of adolescent sexual excess: Young women and wanting. In A. Haris (Ed.), New wave cultures: Feminism, subcultures, activism (pp. 83-102). New York: Routledge.

Ong, A. (2006). Neoliberalism as exception: Mutations in citizenship and sovereignty. Durham: Duke University Press.

Parreñas, R. S. (2000). Migrant Filipina domestic workers and the international division of reproductive labor. Gender E' Society, 14(4), 560-580.

Parreñas, R.S. (2001a). Transgressing the nation-state: The partial citizenship and "imagined (global) community" of migrant Filipina domestic workers. Signs: Journal of Women in Culture E' Society, 26(4), 1129-1154.

Parreñas, R.S. (2001b). Servants of globalization. Stanford, CA: Stanford University Press. 
Parreñas, R.S. (2008). The force of domesticity. New York and London: New York University Press

Pratt, G. (2004). Working feminism. Temple University Press.

Pratt, G. (2012). Families apart: Migrant mothers and the conflicts of labor and love. Minneapolis, MN: University of Minnesota Press.

Pratt, G., \& Rosner, V. (2006). Introduction: The global \& the intimate. Women's Studies Quarterly, 34(1\&2), 13-24.

Republic of the Philippines National Statistics Office (2013). Total number of OFWs is estimated at 2.2 million. Retrieved from: http://www.census.gov. $\mathrm{ph} /$ content/total-number-ofws-estimated-22-million-results-2012survey-overseas-filipinos
Rodriguez, R.M. (2010). Migrants for export: How the Philippine state brokers labor to the world. University of Minnesota Press.

United Nations Population Division (2012). The age and sex of migrants 2011. Retrieved from: http://www.un.org/en/development/desa/population/ publications/migration/age-sex-migrants-2011.shtml

Weis, L., \& Fine, M. (2012). Critical bifocality and circuits of privilege: Expanding critical ethnographic theory and design. Harvard Educational Review, 82(2), 173-201. 